Assurances et gestion des risques

Insurance and Risk Management

\title{
Assessing and Re-setting Culture in Enterprise Risk Management
}

\author{
Harold Weston, Thomas A. Conklin et Kristen Drobnis
}

Volume 85, numéro 1-2, juin 2018

URI : https://id.erudit.org/iderudit/1051319ar

DOI : https://doi.org/10.7202/1051319ar

Aller au sommaire du numéro

\section{Éditeur(s)}

Faculté des sciences de l'administration, Université Laval

\section{ISSN}

1705-7299 (imprimé)

2371-4913 (numérique)

Découvrir la revue

\section{Citer cet article}

Weston, H., Conklin, T. A. \& Drobnis, K. (2018). Assessing and Re-setting Culture in Enterprise Risk Management. Assurances et gestion des risques / Insurance and Risk Management, 85(1-2), 131-172. https://doi.org/10.7202/1051319ar
Résumé de l'article

Among the tenets of enterprise risk management (ERM) is the need to instill a risk-aware culture throughout the firm. Yet, how to actually interpret and change organizational culture is generally missing from the ERM literature. Prior surveys found risk managers lacked useful information about organizational culture and cultural change to implement a "risk aware culture.” Our survey of risk managers found this gap persists. The disciplines of organizational studies, business anthropology and sociology provide guidance on organizational culture, which involves identifying and interpreting the embedded assumptions, values, myths, artifacts, rituals, and stories that communicate and perpetuate a culture. The risk manager can use this knowledge to apply change to the culture. Changing behavior without changing culture may simply result in compliance without adoption. This article seeks to bridge the studies of organizational culture and change to the risk manager.
Tous droits réservés $\odot$ Faculté des sciences de l'administration, Université Laval, 2018
Ce document est protégé par la loi sur le droit d'auteur. L’utilisation des services d'Érudit (y compris la reproduction) est assujettie à sa politique d'utilisation que vous pouvez consulter en ligne.

https://apropos.erudit.org/fr/usagers/politique-dutilisation/ 


\title{
ASSESSING AND RE-SETTING CULTURE IN ENTERPRISE RISK MANAGEMENT
}

\author{
Harold WESTON1, Thomas A. CONKLIN², Kristen DROBNIS 3
}

\section{ABSTRACT}

Among the tenets of enterprise risk management (ERM) is the need to instill a riskaware culture throughout the firm. Yet, how to actually interpret and change organizational culture is generally missing from the ERM literature. Prior surveys found risk managers lacked useful information about organizational culture and cultural change to implement a "risk aware culture." Our survey of risk managers found this gap persists. The disciplines of organizational studies, business anthropology and sociology provide guidance on organizational culture, which involves identifying and interpreting the embedded assumptions, values, myths, artifacts, rituals, and stories that communicate and perpetuate a culture. The risk manager can use this knowledge to apply change to the culture. Changing behavior without changing culture may simply result in compliance without adoption. This article seeks to bridge the studies of organizational culture and change to the risk manager.

\section{INTRODUCTION}

Among the tenets of enterprise risk management (ERM) is the need to instill a culture of risk-awareness and the shared responsibility for risk management firm-wide. But identifying corporate culture and then changing it are skills little known to risk managers. Fraser (2008) surveyed the field and found little information about corporate culture for the risk manager. Bromiley et al. (2014) found similar results. Our survey in 2016 found the problem persists. As Bromily observed, "The ERM field has taken a naïve view of organization change. The academic literature largely assumes that appropriate incentives or objectives will result in organizations adopting appropriate risk practices. ... However, management scholars have a history of organizational change studies that could inform risk management." (2014, p. 272). 
The social sciences have contributed deeply to corporate/ organizational culture studies, as will be discussed below. The social sciences have also contributed to the study of risk perceptions, culture, and communications at the individual and macro levels: Breakwell (2007), Douglas and Wildavsky (1982), Pidgeon, Kasperson and Slovic (2003), Johnson and Covello (1987), Lupton (1999), Harwood (2009), Wendling (2012), Boholm (2003), and Asselt (2011). Beyond this, some studies have examined the sociology of risk as modern versions of sin for older morality-based communities (Moore \& Burgess, 2011; Ericson \& Doyle, 2003; Douglas \& Wildavsky, 1982; Athanassoulis \& Ross, 2010). Despite this work, there has been little contribution from the social sciences regarding understanding risk at the corporate/organizational level. Our aim here is to connect these two academic subjects so that the implementation of ERM's "risk-aware culture" can be informed and implemented with the techniques of organizational culture studies.

Our focus on corporate culture as a way to manage risk and implement a risk-aware culture for ERM may be new ground for quantitative risk managers and modelers; see for example McNeil, Frey, \& Embrechts (2015), who focused solely on the quantitative side of this field as a result of dramatic events and changes in the financial risks of organizations in the early $21^{\text {st }}$ century. The economic studies of risk preferences will not help much because classifying people as risk takers, risk averse, or risk neutral does not sufficiently address the group behaviors that evolve from many other individual and social factors, nor help with identifying the other social factors and cues that motivate people to be risk aware, nor help with shifting people from being risk takers to either neutral or averse. (See for example, Charnes, Gneezy \& Imas, 2013, on the limitations of eliciting risk preferences in complex environments; and Crespo, 2013, on the need to use practical (human) reason that selects ends and means, and not only technical or instrumental reasoning in economic models.) The idea of incentives also insufficiently explains individual and group behaviors (Bromily, 2014), and indeed has often led to results that were contrary to the intended result. As we note later, incentives may lead to compliance, and compliance may affect behaviors, but compliance has high monitoring costs whereas culture is self-directed and group-directed.

We first examine ERM and the exhortations to address and instill a risk-aware culture in ERM. Then we examine organizational culture through the principal studies. We address corporate typologies and how this is a starting point for managers, and in particular chief risk officers (CRO's), to understand their corporate cultures. Then we 
present our survey results of practicing risk managers to establish the gap in knowledge and understanding among practicing risk managers, which supports the purpose of this paper to bridge the two studies of organizational culture and corporate risk management. Finally, we show how to evaluate and use the leading frameworks of Kotter (1995), Bridges (2009) and Schein (2010) to change organizational culture, all with a focus on doing so for ERM.

\section{ENTERPRISE RISK MANAGEMENT PERMEATES THE FIRM}

In traditional risk management the risk manager had sole or primary responsibility for assessing and managing risk. This included assessing hazard or pure risks, and operational risks, then applying conventional risk management techniques to reduce losses and to purchase insurance to pay for any losses, and then handling claims that arose from the losses. The firm's attorneys shared responsibility for the contract and product risks that might lead to liability claims, and the human resources department shared responsibility to look after worker safety and workers' compensation claims. Finance and treasury looked after the money.

Enterprise risk management brings all three domains together, with the chief risk officer serving as leader for assessing all the firm's risks and their impact on value. This requires the CRO to collaborate with many other officers and departments. Because the CRO cannot possibly know all risks - even with the best risk maps and risk registers - everyone in the firm must develop an appreciation for risk within their domain (operations, strategy, finance, and the particular domains thereunder), and share their relevant knowledge with the CRO to assess, correlate, aggregate, and then ameliorate the key risks to acceptable levels within the risk tolerances set by management and the board of directors. Under ERM, separate risks may be tolerable in isolation, but finding linkages to other separate risks may reveal interrelationships that amply the impacts to intolerable levels. All of this is in service to building corporate value and achieving objectives (Segal, 2011).

There are several definitions of ERM (e.g. Ai, 2012; Altuntas, 2011; Buck, 2012; Chapman, 2011; COSO, 2004; Elliot, 2012; Pagach, 2011). Segal focused on corporate value for ERM, defined as "The process by which companies identify, measure, manage and disclose all key risks to increase value to stakeholders" (Segal 2011, p. 24). This is different 
than shareholder value, which is usually measured in stock prices. For this paper, we have no preferred definition of ERM as risk management itself has different meanings depending on the firm: financial firms have a different risk exposure and thus different risk management than non-financial firms.

\section{ENTERPRISE RISK MANAGEMENT GLANCES AT CULTURE}

Many authors have claimed that enterprise risk management requires a new "risk culture." (Altunas, 2011; Banks, 2012; Ernest \& Young, 2009; Ernest \& Young, 2012; McCormack, 2013; Moeller, 2007). "The precondition for a successful risk strategy is an effective risk management culture. A risk management culture describes the way in which the firm handles its individual risks and is affected by the corporate culture" (Altunas, 2011, p. 419). Louisot (2009) provided a chapter-length discussion of organizational culture, which mostly came down to listing six types of corporate culture (adaptive, inert, networked, mercenary, fragmented and communal) and suggested a risk attitude continuum. Fox (2009) listed culture as a core attribute that executive management should assimilate into front-line management. Even in the quantitative world of finance, "a company's success is closely linked to the role risk plays in its culture" (Buehler, 2008, p. 98). All, however, fail to explain what culture is, how the risk manager should identify the culture, or how to change it. Roeschmann (2014) went the furthest by bringing the organizational studies of culture to her focus on risk culture among insurers; importantly, she noted the absence of Schein's work in the risk culture literature. This is significant as Schein is considered a cornerstone theorist/practitioner in the organizational studies field. His important book, Organizational Culture and Leadership, (2010), now in its fourth edition, has been cited 34,527 times (Google Scholar).

Sometimes culture refers to the "tone at the top," suggesting that the senior officers and the directors need to set the tone, emphasis, and direction. "Senior organizational members are always, in one way or another, 'managing culture' - underscoring what is important and what is less so and framing how the corporate world should be understood" (Alvesson 2002, p. 1; similarly, Banks 2012, p. 31). Often, advice about corporate culture is more about changing a few targeted behaviors through repetition, such as moving from compliance with OSHA (the U.S. Occupational Safety and Health Act) to overall worker safety. For example, Moody (2013) and others (LeFever-Watson, 2013a, b; 
Naevestad, 2009; Tharaldsen \& Haukelid, 2009) emphasized that culture should be considered separately from behavioral aspects. This is more like social structure in terms of mapping behavioral patterns and social interactions (Alvesson, 2002, p. 5). Further distinctions of culture focus on whether risk managers are qualitative types or quantitative types (Buck, 2012; Mikes, 2008).

Banks in his book Risk Culture (2012) addressed risk culture using the management techniques of competency, leadership, accountability, governance, and incentives, with a defined risk philosophy and risk appetite. He said these must become "intuitive and so embedded in the fabric of an institution that they exist subconsciously" (p. 18). Yet he expressly declined to include "an in-depth discussion of organizational or corporate culture" (p. 21-22). Weick is one of the foremost writers on organizational culture, yet his book, Managing the Unexpected, addresses corporate "resilience and safety through 'mindfulness' and the need to change people's feelings" (Weick, 2001, p. 117-147). He mostly omits his insights on organizational culture and how to construct it, which we will discuss later.

If CRO's are supposed to instill higher value (Hoyt, 2011; Leibenberg, 2003; Pagach, 2011), and culture is important to instilling risk awareness in the firm, then risk managers need additional information. This is where studies of organizational culture by business anthropologists, sociologists, social psychologists and management studies are useful to the CRO. The purpose of this paper is to bring social science knowledge to the work of the $\mathrm{CRO}$, who is compelled to deal with corporate risk culture yet is left empty-handed on how to do that.

\section{ORGANIZATIONAL CULTURE}

A firm is a community of some type (Adler 2006; Nisbet, 1969; Pina e Cunha, 2014; Solomon, 1992) and as such has its own relationships, values, customs, practices, and thus culture (Campbell \& Göritz, 2014), even one that may be corrupt (Campbell \& Göritz, 2014). This makes it a subject for anthropologists and sociologists, who have been studying organizations since the 1930's (Jordan, 2010; Scott, 2004), and for social psychologists; we note William $\mathrm{H}$. Whyte's classic book, The Organization Man (1956). Business anthropologists study group behaviors and corporate cultures; they are interested in beliefs within and between groups, across various cultures and the world, as well as 
within organizational contexts. This allows them to better understand human behavior from the participants' perspectives (Jordan, 2010). When business anthropologists study cultural variables such as beliefs and values, social structure, and gender-related behavior differences in organizations, they try to answer questions such as, "Why do people do what they do?" and "What do they mean when they do so?" (Tian, 2010, p. 70-71). Aguilera described it as, "when how becomes why, the meta-language of anthropology becomes important" (1996, p. 739). Business anthropology is effectively divided into three fields: Organizational anthropology (the study of complex organizations including their cultures, work processes, and change directives), with an internal focus useful to risk managers trying to change the culture. The second field is anthropology of marketing and consumer behavior (Tian \& Walle, 2009). The third field is design anthropology including product and services design (Jordan, 2010). These last two fields of business anthropology direct their focus externally to the business environments of markets and product use.

Culture comprises the elements and boundaries of a community, and business organizations constitute one type. Nisbet's description of communities in society states: "Community is the product of people working together on problems, or autonomous and collective fulfillment of internal objectives and of the experience of living under codes of authority which have been set in large degree by the persons involved" (1953, p. xiv). Academic interest in organizational culture and management became a significant focus of management science in the 1980's (Corporate Culture, 1980; Jordan, 2010) and has led to the publication of over 4,600 articles (Hartnell, 2011). People are often unaware of their culture as a culture. "[M]anagers who have grown up in an organization often don't realize they even have a culture" (Watkins, 2007, p. 30). In fact, it is these same managers who foster the culture, perhaps unwittingly, as mentors to younger employees (Grody, 2012). Culture is "a set of basic assumptions that defines for us what to pay attention to, what things mean, how to react emotionally to what is going on, and what actions to take in various kinds of situations" (Schein, 2004, p. 31-32). It is the "underlying, unquestioned - but virtually forgotten - reasons for the way we do things here" (Ott, 1989, p 3).

"[O]rganizational culture perspective focuses on ... basic assumptions, cognitive patterns, values, myths, and unspoken beliefs. ... It is not noticed unless it changes suddenly." (Ott, 1989, p. 8). Typically, only when a person from a different culture enters a new cultural system does the person perceive more clearly the culture from which he/ she came. It is when new employees hear things like, "I'm sure you're 
not trying to cause trouble here but you're new and we expect people will do things this way," or "I'm used to having one manager approve something, but here you want me to get the group's approval first," that they become aware of the new and different cultural norms present in the organization that they have now joined. Stories reflecting this dynamic are legion. The IBM consultant is a gawky standout when entering Google's or Apple's campus. Hardware companies and software companies are culturally different (Enthoven, 2014). Airline mergers reportedly take years to integrate organizational cultures. For instance, when Delta and Northwest airlines merged, the flight attendants had to reconcile their definitions of service: Delta flight attendants thought service meant pouring drinks into cups, Northwest's thought service meant giving the entire can or bottle to the passenger rather than limiting the beverage to cup-size (Mouwad, 2011). Schein provided examples of companies where interrupting at meetings was common; despite the frustration and conflict such interruptions caused, it was important for that company to challenge and then validate ideas (Schein, 2004, p. 233-239). Another example (of many) he gave was management's desire for engineering staff to stop being parts of projects and instead promote their expertise and charge a fee, yet the engineers hated it because they felt engineering work meant good work, not creating a thing to be sold (Schein, 2004, p. 4-6).

The purpose of culture is to "create order, meaning, cohesion and orientation, thus making collective action, indeed organizational life, possible" (Alvesson, 2002, p. 13), while admittedly restricting autonomy, creativity and questioning. Granted, the right culture will also foster these attributes in ways productive to the organization. "Perhaps the most intriguing aspect of culture as a concept is that it points us to phenomena that are below the surface, that are powerful in their impact but invisible and to a considerable degree unconscious. In that sense, culture is to a group what personality or character is to an individual," explains Schein (2004, p. 8). Hence, we witness behavior as the outward manifestation of culture but have no access to the underlying values, beliefs, and philosophical structures that support such behavior. Alvesson explains that "culture refers to what stands behind and guides behaviour rather than the behaviour as such" (Alvesson 2008, p. 36). Culture can serve as an exchange-regulator (what is in the best interest of the organization), as compass, social glue, sacred cows (internalized ideals and values), affect-regulator, and on the other side as a system of disorder, blind world-closure that makes it impossible to question (Alvesson, 2002, p. 31-35). As example, Grody (2012) observed that partners in large investment firms, when they were 
partnerships and not corporations, had a "feeling of closeness, ... Culture was transmitted almost effortlessly. In seeing a transgression, it could easily be remedied" (p. 180). Culture, then, was and is an organizing structure that guides and corrects behavior.

In sum, the CRO may want to consider that culture can be thought of as the acceptable behaviors within an organization that comply with the stated and unstated values, beliefs and philosophies of the organization that have been intentionally, or unwittingly sanctioned by those in power. Categories to consider, which might make this fuzzy idea more accessible, include relationships, in- and out-group practices and the beliefs supporting them, what does and what does not get rewarded or punished, the presence or absence and roles of emotional display, the importance of things, and the values and beliefs behind such issues.

\section{TYPOLOGY OF CORPORATE CULTURES}

Two of the more widely cited definitions of culture (of the 164 counted by McLeod, 1984) are the anthropologist Jordan's, who claimed culture as "an integrated system of learned, shared ideas (thoughts, ideals, and attitudes), behaviors (actions), and material artifacts (objects) characteristic of a group" (2010, p. 17); and Schein's, as "a pattern of shared basic assumptions that was learned by a group as it solved its problems of external adaptation and internal integration, that has worked well enough to be considered valid and therefore, to be taught to new members as the correct way to perceive, think, and feel in relation to those problems" (2004, p. 17). The basic assumptions in both definitions include norms, values, behavior patterns, rituals, and traditions (Schein, 2004).

Another way of analyzing corporate cultures is to classify them. Various typologies have been offered for this. Cameron and Quinn (1999) offered four in their popular Competing Values Framework (excerpted from the summary by Hartnell, 2011, p. 678-680): class culture (internally oriented and is reinforced by a flexible organizational structure), adhocracy culture (externally oriented and supported by a flexible organizational structure), market culture (externally oriented and reinforced by an organizational structure steeped in control mechanisms), and hierarchy culture (internally oriented and supported by an organizational structure driven by control mechanisms). Goffee (1998) offered networked (social networks of small creative teams, with 
or without long-term loyalty to the firm), communal (high loyalty and sociability, a family of workers), fragmented (loose alliances of independent employees (physician groups, accountants, lawyers, etc.) with low sociability and loyalty to the firm), and mercenary (winning is everything, sociability is low). Louisot (2009) in his book on ERM added two to Goffee's list, adaptive (adapts to changes in the external conditions) and inert (we've always done it this way). Schein (2004, p. 191) noted coercive, utilitarian, and normative. Other taxonomies also exist. ${ }^{4}$ These may be summarized into four categories: (a) internal with a flexible focus; (b) external with a flexible focus; (c) internal with control emphasis; and (d) external with a control emphasis. These can be further interpreted according to tight (communal) or loose (networked) and independent (fragmented) or competitive (mercenary).

Classifying a corporate culture according to any of these models provides a risk manager with some starting point of understanding her corporate culture, but little understanding of what is enforcing the culture or how to change it. The risk manager will need to understand and use values, symbols, metaphors, myths, and rituals (or ceremonies) that form and sustain those cultures to discern the corporate culture. "The culture messages transmitted by such practices typically express not only explanations of reality, but also norms and values that proclaim to system members the rightness of certain beliefs and practices over others" (Trice \& Beyer, 1984, p. 654). The CRO must next use these "practices" and techniques to change the values, symbols and rituals, or shift their meanings, to create the risk-aware culture espoused in ERM. We expand on these later, after our report on our survey of risk managers.

\section{SURVEY OF CORPORATE RISK CULTURES AND CULTURAL AWARENESS BY RISK MANAGERS}

Our discussions with risk managers revealed that they wanted to understand and change corporate culture to implement ERM's risk-aware culture but largely lacked knowledge of the organizational culture studies and techniques to properly address organizational culture. We then did a survey of risk managers in various organizations to ascertain their actual knowledge of organizational studies and techniques for changing corporate culture, and how effective their efforts were to change corporate culture for ERM. 
We administered the survey (Appendix A) through various U.S. chapters of the Risk and Insurance Management Society (RIMS). We selected the chapters based on overall size of the chapters and included Atlanta, Boston, Dallas-Fort Worth, Los Angeles, Orange County (California), New York, Rocky Mountain, San Francisco (Golden Gate), Silicon Valley, and Washington. The chapters agreed to send e-mails to their members (risk managers who were members of their chapters), which explained the survey and linked to a SurveyMonkey for this study. Contacting risk managers through RIMS' chapters' membership lists did not allow us to limit the survey only to the senior risk managers.

Of the firms that responded, $44.44 \%$ of these firms were privately held, $55.56 \%$ were publicly listed; $39.29 \%$ had only domestic business operations, while $60.71 \%$ operated internationally; and, $28.57 \%$ had sales between 100 million and 1 billion, $71.43 \%$ had sales over 1 billion.

Survey results suggested that staff have some relative risk awareness in many organizations. However, when probed on questions related to literature-based knowledge and techniques that address culture and how to change it, the results varied. While $75 \%$ of the firms responding indicated they had hired or contracted a person/organization with knowledge of organizational culture, only $13 \%$ of the organizations surveyed indicated some knowledge of the work of Edgar Schein, or John Kotter, two academics/consultants who are closely associated with the research and practice of organizational culture and change. Below we provide detailed results of four questions rated on a 7-point Likert (1961) scale, two questions as yes or no (results just listed above, and will be omitted below), and three short answer questions (questions 6, 7, and 8).

The questions rated on a Likert scale were:

1. To what extent are you familiar with the idea of a "risk aware" culture for enterprise risk management? Mean $=4.27$; $\mathrm{SD}=1.60$. This SD suggests some variability among the responses that reveals broad differences in knowledge.

2. Does your firm have what you would describe as a risk aware culture? Mean $=4.56 ; \mathrm{SD}=1.56$. Again, a $\mathrm{SD}$ of this magnitude suggests that two thirds of the respondents indicated a score between 3 and 6.12, a relatively wide dispersion of responses. 
3. Prior to beginning your survey of firm culture, please rate the level of the current risk aware culture at your firm? Mean $=4.30$; $\mathrm{SD}=1.45$. Here, two-thirds of the responses fall between 2.85 and 5.75 on a 7 -point scale, again indicating a broad variation in the level of risk aware culture sensitivity.

4. To what extent have these processes (techniques, frameworks, tools of culture change) achieved their intended result? (This question followed the two inquiries, question 6 and 7, on techniques applied below) Mean $=4.91 ; \mathrm{SD}=.91$. There was greater alignment of responses on this question. Two-thirds of the respondents rated successful interventions as between 4 and 5.82, hence greater agreement in their assessments.

Short response questions and themes of responses are included below. The data was analyzed using thematic analysis developed by Boyatzis (1998), a viable approach to use with numerous sources of data including "behavior samples from interviews, videotaped encounters, simulations, transcripts of speeches, memos, personal letters, or personal diaries" (Boyatzis, 1998, p. 12). Further support comes from Braun and Clarke (2006) who found thematic analysis a meaningful approach for "identifying, analysing and reporting patterns (themes) within data" (p. 79). All three steps of Boyatzis' (1998) method were applied, which included addressing sampling and design issues. This was addressed in the selective approach of organizations and their members who could meaningfully report on culture and risk. Secondly, the development of themes and a code was completed using the verbatim language of the responses. This avoided any interpretation or reframing by us and enabled us to maintain the integrity of the data. Finally, the code was validated through its application to the data using Braun and Clarke's (2006) definition of themes. They claimed that a theme is "something important about the data...and...some level of patterned response or meaning within the data set" (p. 82). Below, we have organized representative participant responses according to theme. We also provide data on which question generated the most responses for each theme. Complete responses can be found in Table 1 in the appendix.

Education and Training: Education and training emerged in response to question 7. Participants claimed that "education," "training," and employing "leaders as teachers" were techniques used to understand the firm's culture. Question 8 also revealed that education and training 
are central in shaping or changing firm culture. Phrases such as, "We use education and training," "cross-training," "email awareness of common hazards," "distribution of internal and industry trade information," and "eLearning modules," were cited as methods by which this is accomplished.

Assessment and Measurement: Questions 6, 7, and 8 all contained references to assessment and measurement issues. This theme was identified from question 6 which focused on how firms understood a risk-aware culture. Phrases reflecting this include "Risk assessments are considered prior to taking on new activities" and "risks must be evaluated before beginning any task, no matter how routine." This theme also emerged from question 7 responses which inquired into the frameworks, tools and methods firms use to understand firm culture. Phrases and words such as "surveys," "assessments," "audits," "measurement," and "interviews" suggest that some form of assessment or data collection was conducted to determine the current culture. Finally, question 8 asked about methods by which firms shape or change culture. Here, responses included "incident reviews," "worksheets," "oversight groups," and "audits."

Values: The final theme shared across more than one question referred to values as an element of culture. Question 6 generated quotes such as "a set of values beliefs, knowledge and understanding surrounding risks that are shared by a group of corporate citizens with a common objective of furthering a corporate mission," and "A philosophy that is thoroughly understood and agreed by all levels of an organization." Question 8 also generated responses along this theme, however, there was little detail as to how this focused on risk-awareness, hence, we can only infer that respondents may have been referring to risk in these comments. Finally, one respondent's reply included using financial incentives to increase risk-awareness. Specifically, this person said, "The first step we've taken is to impact our stores financially at the time of a loss by raising their deductibles...Now they have more 'skin in the game' so to speak." This reveals another avenue by which organizations can instill greater awareness to this important issue.

Other themes that surfaced were care and sensitivity, which came from question 6. "People strive to intimately understand the risks inherent in their own areas of responsibility; and their impact on risks in other areas of the enterprise," and "Employees are aware of risk and not afraid to raise concerns." These show a rich understanding that reveals high levels of awareness to sensitive data and decisions. Lastly, communication was identified in question 8 as a method to instill 
sensitivity to risk. Quotes supporting this theme include: "Executive messaging," "tone at the top," "Transparency and open communication," and "Leadership messaging."

These results confirmed our sense that risk is an important issue in organizational life, but only for some. Others may not know enough to compel them to attend to these issues, especially as they strive to complete the tasks of their work, which are likely very consuming. Still, it is probable that many managers in risk departments and beyond know something about organizational change simply as a function of their ascension in the organization and their time in the workforce, despite being unaware of the language, techniques, literature, or theory surrounding this field. This possibility may have caused a downward bias to the survey results that inadvertently and inaccurately reflects less knowledge than what is actually present.

\section{Changing CULTURE}

Having confirmed previous findings of risk managers' weak knowledge of organizational culture techniques, we seek here to implement Bromily's (2014) recommendation to bring the discipline of organizational change to risk management for the purpose of implementing a risk-aware culture for ERM. There are various methods to change culture, widely applied. A popular model posited by Lewin (1951) is commonly described as a process where the organization will "unfreeze," "change" and then "re-freeze" the new culture (Gibson, 1980, pp. 171-174, citing Lewin, 1951). Unfreezing means destabilizing the status quo of group norms and values. The intent is to convince the group of the necessity for the change (Alvesson, 2008, p. 20). The process may include "unlearning," which means "eliminating beliefs, routines, and physical artifacts in organizations based on the insights garnered from the cognitive psychology, organizational memory and change literature" (Akgün, 2007, p. 797). New routines are only as successful as the attempts at unlearning past processes (Akgün, 2007). To Lewin's second point, change is the process of instituting new processes, values, and metaphors that will lead to the desired behaviors reflecting those new values, metaphors, etc. Finally, re-freezing seeks to instill and cement those new processes, values, metaphors, and beliefs into the new culture so the new process, practice and behaviors become the way work gets done in the organization. This requires detailed efforts to be successful and generally takes much longer than 
managers would like to imagine. The $\mathrm{CRO}$, in applying these ideas and techniques for ERM, must use new or updated symbols, values, rituals and practices to modify behaviors and add risk awareness to the culture. This requires a predicate understanding of the existing culture - beyond basic typologies - and why employees do the things they do based on what they value.

While Lewin's model provides a broad sense of direction for change, it is important to understand the details of this process. Kotter (1995) designed an 8-step process for instituting change, thus leading to organizational culture transformation. We provide a brief review of the steps here with more inclusive descriptions and applications below.

1. Establish a sense of urgency. A crisis mentality is at the heart of this step where organizational members feel imminent corporate demise if something is not done. A major loss to the company, however that is defined or interpreted, creates that sense of urgency.

2. Form a powerful coalition of powerful people at the top of an organization who champion and support the change initiative.

3. Create a compelling vision of the future that is easy to communicate and appeals to stakeholders of all stripes.

4. Communicate the vision. There must be an enormous amount of credible communication of this vision to capture the hearts and imaginations of staff at all levels.

5. Empower others to act on the vision. This often requires that organizations restructure systems, processes, and practices of the culture that may block the new behaviors to associate with the new vision. Managers must also encourage through the new systems, processes, and practices the desired behaviors that underpin the new culture.

6. Establish processes to celebrate short-term wins by identifying moments and events so staff see progress towards the ultimate goal of transformation.

7. Consolidate improvements and establish processes to continue the change towards the new behaviors and practices that ultimately form the culture. The momentum of the short-term wins can serve as an impetus for continued change in the processes and practices that will cement these changes into the cultural fabric of the organization. 
8. Establish the changes as the fundamental scaffolding in the organization's culture and institutional icons. Change to the new culture is successful when members say this is "the way we do things around here" (Kotter, 1995, p. 67). This is most likely when there is a clear understanding of how these changes have led to the firm's success.

The following section identifies actions and details aligned with each of Kotter's 8-steps on how managers can change culture, and in particular how CRO's can use these steps to instill a more risk-aware cultural norm for ERM. We also weave in the work of Bridges (2009) on changing organizational culture.

\section{Step 1 - CREATE A CRISIS}

It is easier to change culture if the firm is in crisis since the old behavior patterns stand out against the backdrop of inadequate results. Kotter (1995) claimed that a crisis is more mobilizing than a gradual and slow change process. Urgency has the power to mobilize many resources that can be brought to bear against the "burning platform." There are two risks: the firm's management may fail to truly accentuate the crisis nature of the situation in terms serious enough to compel change (perhaps for its own reasons to downplay the crisis), or management may create an artificial crisis that undercuts its credibility. It is perhaps more accurate to say that urgency is the real motivator, which is easiest to elicit if a real crisis is in progress. Then the severity of the danger drives the feeling of impending doom if something is not done. Real life scenarios of the dismal future should be crafted to anchor the possibility in the minds of those who need to act. That includes employees, obviously, and all stakeholders (e.g. suppliers, customers, distributors, lenders, shareholders, etc.) who may have interests on the ongoing success of the firm. For CRO's this means painting real world pictures of the danger and of the opportunity that can be seized by immediate action. To be successful, honest and transparent dialogue must pervade the organization at all levels. Staff have to know and feel their multiple and shared skills are essential to address the present threat and avert the crisis. 


\section{STEP 2 - FORM A POWERFUL COALITION}

For the CRO, the composition and drivers of a powerful coalition will be determined in part by whether there has been a major loss or exposure (a crisis - e.g. explosion, large losses of life, financial meltdown, criminal investigation such as violation of the Foreign Corrupt Practices Act or bank regulator pressure from past practices, etc.) or whether the firm seems to be performing adequately and simply wants to do better. CRO's routinely try to imagine, project, and model probabilities of losses and their severity, which are informative to both senior management and can be used to capture the hearts and curiosities of the staff lest they fail to impress on them the urgency of the situation as created in step 1. Management may choose to appeal to the pride the employees take in doing something well, and the corollary experience of the risks that would impair that success and their attending experience. The coalition must include senior management, and the collation must speak with one voice.

\section{Step 3 - CReATE A COMPELLING VISION}

Creating a vision that makes rational sense, and also appeals to the rich emotions among staff, is critical for the change to take place. Kegan and Lahey $(2001,2009)$ have discussed the resistance people have to change and cite research on patients with coronary disease and their seeming inability to alter their lifestyles when given the dire facts that if they do nothing they will die in six months. Surprisingly, only one out of seven patients actually makes the changes necessary to sustain life. Human behavior is guided by narratives, not facts. When a fact doesn't fit our conceptual frames - the metaphors we use to make sense of the world - we reject it. Change, then, is inspired best by emotional appeals rather than factual statements, while facts simply provide the rational reasons.

Culture reinforces resistance because culture embodies practices, attitudes, and beliefs as to how things should be done, and what has served the community well for explaining and interpreting events. "Organizations possess a powerful immune system that defends the status quo and resists change" (Gilley, 2009, 4). Strong cultures resist change strongly (Sørensen, 2002). Senior employees may be the most 
culturally settled and their own identities are often bound to the organization. Professionals too may view any change in their autonomy or practices as compromising their crafts (Alvesson, 2008; Maccoby, 2006). Therefore, appeal to purpose and existing values in convincing others that the change is right (Alvesson, 2008; Maccoby, 2006).

In service to crafting the vision and related narratives, Bridges (2009) can amplify this part of Kotter's process. Bridges' system is called the 4 P's of change: picture, purpose, plan, and part. To begin, management should construct a "picture" of the future, essentially a vision, and describe this future picture (vision) and its central values to staff in compelling terms. A vision that has this visceral quality is more likely to compel action among those whom leadership relies upon to manifest the organization's future. The vision of the desired risk-free (or riskaware or risk-attenuated or risk-controlled) future caught in two to three sentences can command powerful commitment. The vision and message should be concise and echoed by all within the organization. We illustrate this point with the urban legend attributed to Hemingway and his tradition of the six-word poem: "For sale, baby shoes. Never worn." What can be said in the fewest words with greatest impact? Rhetoric, to work, requires appeals to emotions and practical reasons.

What does the organization hope to accomplish by making the change? What are the threats and opportunities presented by such a change and why is it worth the risk to pursue them? These questions will lead to the reason for the new vision and the goal of the new vision, then to the communication that follows. For the third P, management should construct a detailed "plan" for how the change is to unfold, using multiple voices and leaders in the organization (Bridges, 2009). For the CRO dealing with ERM, this means moving the risk-awareness from the risk management department to all staff and then receiving back the early warnings of such risks.

\section{Step 4 - COMmunicate the CHANGE}

Every new change program has to build excitement and anticipation. "This can be achieved by delivering the information about the change in a positive tone and using trustworthy communicators in a pleasant environment" (Fox, 2001, p. 87). The reasons for the change have to be explained including why the past is not working now and will not 
work in the future. Management must provide a view to the future that will result in a clearer "picture," as Bridges (2009) suggests, that results in a vision of where the firm needs to go. How will the organization sustain its safety and relieve it from the risks in the external environment?

Metaphors are another form of story to communicate, (which aligns with Kegan and Lahey's (2001, 2009) work cited above). A metaphor is "a figure of speech containing an implied comparison, in which a word or phrase ordinarily and primarily used for one thing is applied to another, e.g., the curtain of night" (Fox, 2001, 88). Metaphors use more symbolic language and images that are more emotionally laden, and metaphors are effective devices for transmitting and creating these symbolic realities that accompany and give meaning to the more objective reality. At Enron, for example, employees used the laws of the jungle as metaphors to convey their ruthlessness in devouring everything of value, and those who didn't measure up would be "cut from the herd." A former Enron executive recalled that, "at Enron, you had hunters, skinners, and hangers-on. You'd get a big carcass that the organization would dive all over and strip of all the value - skin, bones, and meat" (Mouton, 2012, pp. 325-326, quoting McLean \& Elkind, 2003). These metaphors make it easy to classify Enron's culture as "mercenary" in the typology given earlier.

Extended metaphors are called myths. These have some historical truth, are understood as being partially false, but convey more about beliefs and values than facts (Bolman \& Deal, 2008; Ott, 1989). Beliefs and values provide justifications for behavior (Ott, 1989). Bolman and Deal (2008) said "myths transform a place of work into a revered institution and an all-encompassing way of life" (p. 254). Thus, a story (or myth) about an executive who missed a flight or important business meeting to help a handicapped person get across town or gave up his/ her seat on the plane for that person, will convey more about the personal values of the company than any code of conduct will ever impress on the employees. Consider the news story that the CEO of Delta Airlines, Richard Anderson, gave up his seat so a mother could get home to pick up her child at summer camp; Mr. Anderson then sat in the jump seat in the cockpit (Mutzabaugh, 2013). It's barely worth noting that the following week, the Department of Transportation fined Delta $\$ 750,000$ for violating rules on overbooking passengers (NPR, 2013), which we may surmise Mr. Anderson knew was coming and thus led to promoting the better story the week earlier when he gave up his seat for a mother to get home. 
The use of story is a powerful means of change. Similar to the power of stories in crafting a vision in step 3, it has similar power in communicating that vision to staff. "Stories remind people of key values on which they are centralized. ...Stories are important, not just because they coordinate, but also because they register, summarize, and allow reconstruction of scenarios that are too complex for logical linear summaries to preserve" (Weick, 1987, p. 125). Stories create sense by giving framing and symbolization to ambiguous environments, while also allowing individuals some room to interpret the experience as lived (Islam, 2013). The human connection to stories is why journalists find personal angles to policy decisions: the person without medical insurance, the person wrongfully convicted or wrongly released, the cancer clusters, the victim of predatory lenders. Wiessner (2014) found that storytelling is fundamental to humans and allows them to learn information about how to handle situations they did not themselves experience, in an entertaining way. Storytelling may even have evolved with the discovery of fire (Wiessner, 2014). Weick (1987) gave the example of an engineer who tried to impress upon his audience of engineers the corrosive effects of chemicals on some materials. To do so he dropped a piece of chicken meat in corrosive liquid and then removed the remaining bone. A lecture on the chemical properties was shortened and made memorable by a chicken bone. Ritz-Carlton hotels are famous for their culture of service, which is reinforced every day when the staff lines up before their shift and have the opportunity to present a "wow story" of pleasing a customer. That wow story sticks with employees, such as the waiter who overheard a guest say it was a shame he couldn't get his wheelchair-bound wife to the beach - and then had the maintenance crew build a walkway that night, with a tent at the end (Reiss, 2009). Stories like this relate particulars to universal, and facts into a collectively shared lifeworld (Islam, p. 2013, 34). ${ }^{4}$

Relevant to risk-awareness, stories have been shown to be effective tools that induce (intentionally and unintentionally) specific emotions which can guide cognitive appraisals and behavior. Visschers, et al. explained that "stories provide easy-to-understand cues about risks so that receivers can form mental maps, ... which make the risk information easy to imagine the portrayed situation as real and make it personally relevant" (2012, p. 261). Stories provide avenues by which risk managers can embed greater sensitivity to salient topics in the minds of staff whose work is traditionally unconcerned with such issues. 


\section{STEP 5 - EMPOWER OTHERS TO ACT}

Empowering others ties to Bridges' (2009) $4^{\text {th }} \mathrm{P}$, "part," as in the part each person in the organization will play in achieving the future "picture" of the firm. Doing so can alleviate much of the anxiety and ambiguity that is inherent in change initiatives while giving staff the sense that they have been considered in the long-term interests of the organization. In all steps of the process the significance of risk can be discussed in open environments that can provide greater understanding of what is happening and a deeper appreciation of the risks of doing so. This ongoing dialogue regarding risk tacitly and explicitly places risk concerns at the front and center of the conversation. This serves to institutionalize risk as a salient issue about which all need to be concerned in their daily tasks. Risk-awareness becomes insinuated into the DNA and culture of the organization. For example, the Campbell's Soup Company had a "play it safe" culture that valued consensus before action. To move the company to new products and markets required the CEO to build on that culture and history for its existing customers. But he had to add a new value of courage so that employees felt empowered to take responsible business risks and actions and set ambitious goals. The result was that "people now own the outcomes they deliver" and the company rewards those who make exceptional impacts (Morrison, 2014).

At Aetna, the CEO was able to change the company culture by reaching deep into company history to re-instill pride and customer service, and patiently explaining to employees that the changes, while focused on cost-cutting, were consistent with the deep values of the old company. "[I]nstead of just cutting costs, the organization would pursue a strategy he called 'the New Aetna.' It would build a winning position in health insurance and a strong brand by attracting and serving both patients and health care providers well.... Rowe [the CEO] also made a point of reinforcing a long-time strength that had eroded - employees' pride in the company" (Katzenback, 2012, p. 11). From this, Katzenback offered five principles to implement change, which can also fit within Kotter's and Bridges' frameworks: (1) Match strategy with culture. (2) Focus on a few critical shifts in behavior. Identify the behaviors that matter and reward them, even with gold stars or other types of recognition. (3) Honor the strengths of the existing culture. (4) Integrate formal and informal interventions. (5) Measure and monitor cultural evolution. Katzenback said that organizations tend to focus on the logical, linear, and rational approaches that make good intellectual sense, but fail to understand and appreciate the less structured, more 
informal and emotional elements of organizational change. This "part" ties to vision (picture) and communication, and thereby individual and group behavior by showing employees how they are part of the group values, behaviors and shared interests (Katzenback, 2012).

Another story illustrates the 4 Ps of picture, purpose, plan and part. When Frank Blake became the CEO of Home Depot after the tumultuous leadership of former CEO Frank Naradelli, he had to re-knit the sundered culture that Naradelli had deliberately tried take to apart with little success but with great damage to employee relations, customer service, and customer satisfaction. Blake did a live broadcast, reading excerpts from the biography of founders Bernie Marcus and Arthur Blank, and walked the stores with both founders and had them speak at the annual rally. He also brought back "Homer badges to award store employees for great service, and increased bonus payments six-fold" (Tobin, 2010, p. D1).

While stories are an integral part of crafting the new vision and opening up avenues to new behavior, they can also serve as artifacts that further cement existing culture and act as obstacles to changing behavior. General Motors was excoriated for its repeated failure to identify and own up to a major safety issue with its ignition switches. The company had a culture "where employees avoided responsibility with a 'G.M. salute' - arms crossed and pointing fingers at others - and the 'G.M. nod,' which Ms. Barra [the CEO] described in the report as 'the nod as an empty gesture"' (Vlasic, 2014, p. A1). This was the G.M. culture of saying, I am not responsible, and we are fine if we do not find who is responsible. Stories can also be about the good old days that perpetuate emotional tension with the present, as such stories emerge through gossip and rumor and mistreatment, adding negative emotional weight to an already emotionally overloaded system riddled with conflicting power dynamics that hinder the desired future change. Thus, management must find compelling new stories or reinterpretations of the old stories that open new possibilities for action that will move toward the desired.

Trying to move employees to act in new ways usually creates employee resistance, thus the durability of extant cultures and the brittleness to change. Change creates anxiety (Dahl, 2011) and the attending uncertainty it creates is often met in the only way staff can understand. As Fox (2001) noted:

The new behaviors required by individuals as a result of the change commonly evoke disturbing responses, such as denial, objections, feelings of stress and cynicism, and 
reduced organizational commitment. ... Uncertainty and the perceived loss of control the change program induces are crucial contributors to resistance. In addition, the expected losses to the self and the organization-incurred by the change, and the mistrust employees feel toward the change agents and the process of change implementation, are among the most mentioned reasons for employees' rejection of proposed changes (p. 85).

Schein explained that a challenge to the basic assumptions "temporarily destabilizes our cognitive and interpersonal world, releasing large quantities of basic anxiety" (Schein, 2004, pp. 31-32). This often leads people to distort, deny, and project or in other ways falsify what is going on rather than admit that existing ways of working are no longer functional, and indeed, may be wrong or inadequate to the current reality. Consequently, there is a need to show how the new behaviors and practices will alleviate the stress and anxiety and the crisis. These emotions can be seen positively and leveraged as tools that will facilitate a connection with employees, rather than as a burden to be overcome. (Fox, 2001, p. 87). Nevis (1987) has discussed numerous alternative interpretations of resistance that reveal new facets of the experience for both employee and manager. For instance, resistance prevents one from feeling overwhelmed, resistance represents strength and energy, and resistance is an alternative to the apathy that often meets organizational change initiatives. Seen in this light, resistance becomes a powerful force that can be harnessed to facilitate the change.

\section{STEP 6 - ANNOUNCE IMPROVEMENT WITH SHORT-TERM WINS AND VISIBLE EVENTS.}

At its 2006 shareholder meeting when Home Depot's then CEO, Robert Nardelli, refused to answer questions, particularly as to his pay, and board members failed to attend, investors and analysts became enraged at what they believed was a violation of conduct. Nardelli was promptly sacked after the meeting, although he walked away with $\$ 210,000,000$ in compensation (Home Depot, 2006; Home Unimprovement, 2007). The shareholders' response served as a short-term win that signaled how the firm ought to be run and how management ought to engage with them, thus part of the vision of acceptable and appropriate behaviors. 
The acclimation of new employees to the appropriate norms of the firm should include corporate histories of past leaders, important events, great achievements, the use of mentors or buddies, and tours (or videos). Otherwise, the employee hired and given an employee handbook and an hour with HR to complete paperwork, then assigned to a desk or project without indoctrination of values and behavior, never feels part of the firm and may pursue reckless, unethical actions (Alvesonn, 2002; Johnson, 2011).

\section{StEP 7 - CONSOLIDATE IMPROVEMENTS AND PROCESSES}

Symbols and artifacts are "invested with specific subjective meanings that people associate with conscious or unconscious ideas" (Ott, 1989, p. 21). Many things can serve in this capacity including material as well as behavioral patterns that serve to communicate to others the organization's values, philosophies, and beliefs that underscore the behavior that is witnessed and from which one can infer those values (Ott, 1989). These may include the look and layout of reports and brochures, spatial arrangements in working areas, company cars, furniture, and dress codes (Ott, 1989). As changes in these elements of culture and practice unfold, it is likely that others will complain about how things used to look and be, how standards are not the same, why the reports look different. This is the unpleasant and challenging domain of change that must be lived through in order to instill the new reality. A successful example is something as simple as hospitals that implement monitoring systems to assure that nurses, physicians, and staff sanitize their hands before and after each patient encounter (Economist, 2013). To reinforce the value through symbols, a clean hands badge or pin could be awarded to those with good records. For service workers anywhere "safety merit badges" could be sewn onto uniforms similar to the Home Depot Homer badges given for good service and which are recognized by other employees and customers.

\section{STEP 8 - SOLIDIFY THE NEW APPROACHES}

Kotter discusses the need to articulate and cement the new and effective behaviors and build connections between those behaviors and firm success. This can be accomplished in numerous ways. Promotions and 
appointments of new leadership help staff understand the new reality, values, beliefs, and commitments of the firm to these things. Thus, to unfreeze and change a culture, a ceremony may help to end one practice and begin a new one. "Changes commonly include relinquishing old ways of thinking and behaving and replacing them with new ones. ...ceremonies are effective ways to celebrate the past before departing from it" (Fox 2001, p. 92). To take a customer service desk and smash it in the parking lot boldly signals to all that the former model of providing customer service is absolutely over. Events such as balloons fastened to a cubicle, recognition at the quarterly staff meeting, a page on the internal web portal, or a reserved parking place next to the CEO's for the "risk-employee-of-the-quarter" may create punctuated moments that affirm new directions and successes on the way to the new and future reality of the organization. Then a well-designed process for leadership development and succession ensures ongoing continuity of the organization as reconstructed.

Trice and Beyer $(1984,656)$ provided a typology of corporate rites, well-known in organizational studies, that can further serve to institutionalize the change. They include:

- Rites of passage, using new hire training programs.

- Rites of degradation, for terminations of executives.

- Rites of enhancement, such as on-going training seminars.

- Rites of renewal, to show organizational developments.

- Rites of conflict reduction, such as collective bargaining.

- Rites of integration, such as Christmas and holiday parties.

Ott contends there are essentially four functions of culture which provide: "shared patterns of cognitive interpretations or perceptions; shared patterns of affect, an emotional sense of involvement and commitment to organizational values and moral codes; defined boundaries between members and nonmembers; and an organization control system, prescribing and prohibiting certain behavior" (Grody, 2012; Ott, 1989, p. 68). Trice and Beyer's (1984) "rites" help to instill and reinforce the culture patterns referred to by Ott (1989).

There are, then, several techniques by various leading scholars in the field of organizational studies and corporate culture that can be used alone or blended to assess, implement, and freeze new corporate cultures. 


\section{THE LIMITATIONS OF COMPLIANCE}

The usual solution to past corporate lapses is to impose new compliance measures. Their effectiveness is mixed, and such compliance measures are based on monitoring and negative reinforcement. While compliance controls may change behaviors, the underlying assumptions and values that created the lapse or undesired result will persist. Likewise, training is insufficient as it often is about compliance rather than cultural change. Weick (1987) emphasized that culture works better than compliance since culture internalizes the values that lead to the desired behaviors in individuals and groups, without the need for external control.

Either culture or standard operating procedures can impose order and serve as substitutes for centralization. But only culture also adds in latitude for interpretation, improvisation, and unique action. ... It creates a homogeneous set of assumptions and decision premises which, when they are invoked on a local and decentralized basis, preserve coordination and centralization. Most important, when centralization occurs via decision premises and assumptions, compliance occurs without surveillance (p. 124).

For example, John Briet had a Ph.D. in physics from Columbia University. He didn't think he would be as good a physicist as he dreamed, so he considered either Wall Street or naval intelligence. He went to Wall Street, became the risk manager at Merrill Lynch, and found he was doing mostly intelligence work. According to The New York Times, "He learned that his job was really psychologist, confessor and detective. He became the financial version of a counterintelligence officer, searching for the missed clues and hidden dangers in the firm's trading strategies." The article explained:

Instead of fixating on models, risk managers need to develop what spies call humint - human intelligence from flesh and blood sources. They need to build networks of people who will trust them enough to report when things seem off, before they become spectacular problems. Mr. Briet, who attributes this approach to his mentor, Daniel Napoli, the former head of risk at Merrill Lynch, took people out drinking to get them to open up. He cultivated junior accountants. (Eisenger, 2013). 
Briet's remarks are in line with others on the limitations of systems and procedures which reduce errors but fail to promote excellence and judgment (Cohen, 2013). Instead, a responsibility system, not dissimilar from what Weick (1987) recommended above, requires people to exercise judgment in how to get something done. "It authorises, or empowers, members of the organisation to exercise judgment in decision-making" (Cohen, 2013, pp. 520-521). Experience counts for a great deal when it comes to making risk judgments (Mauelshagen, 2013), but experience without expertise may just be repetition (Weick, 2001). Reasonableness counts a lot, too (Athanassoulis \&Ross, 2010). For the risk manager, the lessons seem to be that accountability systems and procedures serve as risk controls, while responsibility systems using tools of organizational culture can create a risk-aware culture. The group action on individual norms creates a more effective and durable self-regulator of behaviors. Insofar as this applies to ERM, it means imbuing all employees with the risk-awareness, thus their part of being risk-alert and self-directed for risk reduction.

\section{CONCLUSION}

Soft skills are a central element in the creation of desired cultures. Risk managers facing yet another uncertainty - guessing what corporate culture and corporate change mean - can reduce this uncertainty with the scholarship and techniques in the organizational disciplines to help implement the risk culture that underlies enterprise risk management. As Bromily, et al. remarked, "implementation of ERM offers a new and important area in which to study organizational change management" (2016, p. 273). But "what risk culture is and what role it plays in the risk management frameworks of insurers still remain vague. ...this lack of understanding limits the effectiveness of risk management" (Roeschmann, 2014, p. 292). The risk manager may consider engaging a business anthropologist, social psychologist, or organizational cultures specialist to help with a difficult situation. There is a precedent for this as seen when business leaders engage external expertise to facilitate large-scale cultural changes required by strategy changes or crises. Regardless, getting beyond accountability and compliance to instill a risk-aware culture, as ERM claims to do, will require an understanding of and change in the organization's embedded assumptions, rites, values, and beliefs. 


\section{REFERENCES}

[1] Adler, P. S. \& C. Hecksher. 2006, in Hecksher and Adler. 2006. The Firm as a Collaborative Community. Oxford: Oxford University Press.

[2] Boholm, A. 2003. "The Cultural Nature of Risk: Can There Be an Anthropology of Uncertainty?" Ethnos: Journal of Anthropology 68 (2): 159-178

[3] Aguilera, F.E. 1996. "Is Anthropology Good for the Company?" American Anthropologist 98:735-742.

[4] Ai, J., et al. 2012. "Enterprise Risk Management Through Strategic Allocation of Capital," Journal of Risk and Insurance, 79 (1): 29-55.

[5] Akgün, A. E., J. C. Byrne, G. S. Lynn, \& H. Keskin. 2007. "Organizational Unlearning as Changes in Beliefs and Routines in Organizations," Journal of Organizational Change Management 20 (6): 794 - 812.

[6] Alvesson, M. 2002. Understanding Organizational Culture. London: Sage Publications.

[7] Alvesson, M. \& S. Sveningsson. 2008. Changing Organizational Culture. London, New York: Routledge.

[8] Altuntas, M., T. Berry-Stolzle, \& R. E. Hoyt. 2011. "Implementation of Enterprise Risk Management: Evidence from the German PropertyLiability Insurance Industry," The Geneva Papers of Risk and Insurance, 36: 414-439.

[9] Asselt, M. B. A., \& O. Renn. 2011. "Risk Governance," Journal of Risk Research 14 (4): 431-449.

[10] Athanassoulis, N. \& A. Ross. 2010. "A Virtue Ethical Account of Making Decisions About Risk," Journal of Risk Research, March,13(2): 217-230.

[11] Banks, E. 2012. Risk Culture. Houndmills, Basingstoke, Hampshire; New York: Palgrave Macmillan 2012.

[12] Boyatzis, R. E. (1998). Transforming Qualitative Information: Thematic Analysis and Code development. Thousand Oaks, CA: Sage Publications.

[13] Boholm, A, (2003), "The Cultural Nature of Risk: Can There Be an Anthropology of Uncertainty?" Ethnos, June, 62(2): 159-178.

[14] Bolman, L. G. \& T. E. Deal. 2008. Reframing Organizations, $4^{\text {th }}$ edition. San Francisco: Jossey-Bass).

[15] Braun, V. \& Clarke, V. (2006). Using Thematic Analysis in Psychology. Qualitative Research in Psychology, 3(2). 77-101. 
[16] Breakwell, G. 2007. The Psychology of Risk. Cambridge: Cambridge University Press.

[17] Bridges, W. (2009). Managing Transitions: Making the Most of Change. Boston: Nicholas Brealey Press.

[18] Briody, E., T. M. Perster, \& R. Trotter. 2012. "A Story's Impact on Organizational-Culture Change," Journal of Organizational Change Management, 25(1): 67-87.

[19] Bromily, P., M. McShane, A. Nair, \& E. Rustambekov. (2014). "Enterprise Risk Management: Review, Critique, and Research Directions." Long Range Planning, 48: 265-276.

[20] Buehler, K., A. Freeman \& R. Hulme. 2008. "The New Arsenal of Risk Management," Harvard Business Review, 86(9): 93-100.

[21] Buck, D, et al. 2012. "Fuel Risk Management," Risk Management and Insurance Review, 15(1): 1-22.

[22] Campbell, J., \& A. Göritz. 2014. "Culture Corrupts! A Qualitative Study of Organizational Culture in Corrupt Organizations." Journal of Business Ethics, 120 (3): 291-311.

[23] Cameron, K. S., \& R. E. Quinn, et al, The Competing Values Framework: Creating Value Through Purpose, Practice and People, http:// competingvalues.com/competingvalues.com/wp-content/uploads/ 2009/07/Competing-Values-Leadership-Excerpt.pdf

[24] Cameron, K. S., \& R. E. Quinn. 1999. Diagnosing and Changing Organizational Culture. Hoboken: John Wiley \& Sons, Inc.

[25] Chapman, R. J. 2011. Simple Tools and Techniques for Enterprise Risk Management. Hoboken: John Wiley \& Sons, Inc.

[26] Charness, G, U. Gneezy \& A Imas. 2013. "Experimental Methods: Eliciting Risk Preferences," Journal of Economic Behavior \& Organization, 87: 43-51.

[27] Cohen, S. 2013. "Promoting Ethical Judgment in an Organizational Context," Journal of Business Ethics, November, 117: 513-523.

[28] Committee of Sponsoring Organizations of the Treadway Commission (COSO), September 2004. Enterprise Risk Management Framework. Available on http://www.coso.org/documents/COSO_ERM_ExecutiveSummary.pdf.

[29] "Corporate Culture: The Hard-To-Change Values That Spell Success Or Failure.” 1980. Business Week, October 27. 
[30] Crespo, R., 2013. "The Increasing Role of Practice Reason in the Human Development Reports," Review of Social Economy, 71(1): 93-107.

[31] Dahl, M. S. 2011. Management Science, Feb. 57(2): 240-256.

[32] Douglas, M., \& A. Wildavsky 1983. Risk and Culture: An Essay on The Selection Of Techno-Logical And Environmental Dangers. Berkeley: University of California Press.

[33] Dyer, G. 2014. "Shipmates," The New Yorker, April 21: 55-61.

[34] Economist. 2013. "First, Wash Your Hands," The Economist Technology Quarterly. Sept. 7, p. 4.

[35] Eisenger, J. 2013. "Finding the Human Factor in Bank Risk Management," The New York Times. April 4, p. B7.

[36] Elliott, M. (ed.) 2012. Risk Management Principles and Practices, $1^{\text {st }} \mathrm{Ed}$. Malvern: The Institutes.

[37] Enthoven, T. 2011. "A Tale of Two Valleys," New York Times Magazine, March 16, p. 28-22.

[38] Ericson, R.V., \& A. Doyle. 2003. "Risk and Morality." In Risk and Morality, (eds. R.V. Ericsonand A. Doyle), 1-10. Toronto: University of Toronto Press.

[39] Fountain, Henry. 2013. "Unlocking the Potential of Flammable Ice," New York Times, Sept. 17, p. D2.

[40] Fraser, J. K. Schoening-Thiessen, B. Simpkins. 2008. "Who Reads What Most Often? A Survey of Enterprise Risk Management Literature Read by Risk Executives." Journal of Applied Finance, 18: 73-91.

[41] Ernest and Young. 2012, "Progress in Financial Services Risk Awareness," Ernest and Young Survey 2012.

[42] Ernest and Young. 2009. "Top Priority: Creating a Risk Aware Culture," Ernest and Young, February 26.

[43] Fox, C. A \& M.T. Kaiser. 2009. "Building an Enterprise Approach to Risk and Performance," Risk Insight Series, Risk and Insurance Management Society, June.

[44] Fox, S. \& Y. Amichai-Hamburger. 2001. "The Power of Emotional Appeals in Promoting Organizational Change Programs," Academy of Management Executive, 15(4): 84-94.

[45] Frederick, W. C. 1995. Values, Nature and Culture in The American Corporation. Oxford: Oxford University Press. 
[46] Gilley, Ann, M. Godek, \& J. W. Gilley. 2009. "Change, Resistance, and the Organizational Immune System," SAM Advanced Management Journal (Autumn), p. 4-10.

[47] Goffee, R. 1998. The Character of a Corporation, New York: HarperBusiness.

[48] Google Scholar, accessed 3-19-2018.

https://books.google.com/books?hl=en\&lr=\&id=DlGhlT34jCUC\&oi= fnd\&pg $=$ PR9\&dq=+Organizational+culture+and+leadership+by+schein\&ots= -doY8oUhzQ\&sig=JZcqiiFLvQmrHB2uX82UpQOY9Y8\# ${ }_{\mathrm{v}}=$ onepage\&q= Organizational\%20culture\%20and\%20leadership\%20by\%20schein\&f=false

[49] Gupta, M., P. Prakash \& N. Rangan. 2012. "Governance and Shareholder Response to Chief Risk Officer Appointments," The Geneva Papers, 37: 108-124.

[50] Hamada, T. \& W.E. Sibley (eds.). 1994.Anthropological Perspectives on Organizational Culture. Lanham: University Press of America, Inc.

[51] Hartnell, C. A., A. Y. Ou, \& A. Kinicki. 2011. "Organizational Culture and Organizational Effectiveness: A Meta-Analytic Investigation of the Competing Values Framework's Theoretical Suppositions," Journal of Applied Psychology, 96(4): 677-694.

[52] Harwood, I. A., S. C Ward, C.B. Chapman. 2009. "A Grounded Exploration of Organisational Risk Propensity," Journal of Risk Research, 12(5):563-579.

[53] "Home Depot Shareholders Blast CEO Over Pay." 2006. USA Today, May 25, http://usatoday30.usatoday.com/money/companies/management/ 2006-05-25-nardelli_x.htm?csp=34.

[54] "Home Unimprovement: Was Nardelli's Tenure at Home Depot a Blueprint for Failure?" 2007. Knowledge at Wharton, Jan. 10, https:// knowledge.wharton.upenn.edu/article/home-unimprovement-wasnardellis-tenure-at-home-depot-a-blueprint-for-failure/.

[55] Hoyt, R.E. \& A.P. Liebenberg. 2011. "The Value of Enterprise Risk Management," Journal of Risk and Insurance, 78 (4): 795-822.

[56] Islam, G. 2013. "Finding a Space for Story: Sensemaking, Stories and Epistemic Impasse," Journal of Organizational Change Management, 26 (1): 29-48.

[57] Jordan, A. T. 2010. "The Importance of Business Anthropology: Its Unique Contributions," International Journal of Business Anthropology, 1(1): 15-25. 
[58] Johnson, B.B. and V. T. Covello. 1987. The Social and Cultural Construction of Risk. Dordrecht: Netherlands: D. Reidel Publishing Company.

[59] Johnson, J. L., K.D. Martin \& A. Saini. 2011. "Strategic Culture and Environmental Dimensions as Determinants of Anomie in Publicly-Traded and Privately-Held Firms," Business Ethics Quarterly, July, 21(3): 473-502. [60] Karp, H. B. (1996). The Change Leader: Using A Gestalt Approach with Work Groups. San Francisco: Jossey Bass.

[61] Katzenback, J. R. 2012. "Organization Change That Sticks," Harvard Business Review, July-Aug 2012, p. 10-117.

[62] Kegan, R., \& L. L. Lahey. 2001. How the Way We Talk Can Change The Way We Work: Seven Languages For Transformation. San Francisco, CA: Jossey-Bass.

[63] Kegan, R., \& L. L. Lahey Lahey. 2009. Immunity to Change: How to Overcome It and Unlock

[64] Potential In Yourself And Your Organization. Boston, MA: Harvard Business Press.

[65] LeFever-Watson, G. 2013A. "The Science of Behavioral Safety 101: A Little Praise Goes a Long Way," EHS Today, July 30, http://ehstoday.com/ safety/science-behavioral-safety-101-little-praise-goes-long-way

[66] LeFever-Watson, G. 2013B. "A Plan to Build and Sustain a Culture of Safety," EHS Today, July 30, http://ehstoday.com/safety/science-behavioralsafety-101-little-praise-goes-long-way?page $=4$

[67] Leidenberg, A. \& R. Hoyt. 2003. "The Determinants of Enterprise Risk Management. Evidence from Appointment of Chief Risk Officers," Risk Management and Insurance Review, 6(1): 37-52.

[68] Lewin, K. 1951. Field Theory in Social Science. New York: Harper.

[69] Likert, R. (1961). New patterns of management. New York: McGraw Hill.

[70] Louisot, J. \& C. Ketcham, (eds.) 2009. Enterprise-Wide Risk Management: Developing and Implementing, $1^{\text {st }} \mathrm{ed}$. Malvern: The Institutes.

[71] Lupton, D. (ed.) 1999. Risk and Sociocultural Theory, Cambridge: Cambridge University Press.

[72] Maccoby, M. \& C. Heckscher. 2006. "A Note on Leadership for Collaborative Communities," in Hecksher, Charles and Adler, Paul S. 2006). The Firm as a Collaborative Community Oxford: Oxford University Press.

[73] Martin, J. 1992. Cultures in Organizations. Oxford: Oxford University Press. 
[74] Mauelshagen, C, D. Denyer, M. Carter, \& S. Pollard. 2013. "Respect for Experience and Organisational Ability to Operate in Complex and Safety Critical Environments," Journal of Risk Research, Oct., 16 (9): 1187-1207.

[75] McCormack, P. \& A. Sheen. (2013). "Operational Risk: Back on the Agenda," Journal of Risk Management in Financial Institutions, (4); 36-386.

[76] McLean, B. \& Elkind, P. 2003. The Smartest Guys in the Room: The Amazing Rise and Scandalous Fall of Enron. London: Penguin Books.

[77] McLeod, J. 1989. "Ritual in Corporate Culture Studies: An Anthropological Approach," Journal of Ritual Studies, vol. 4 (1): 85-97.

[78] McNeil, A. J., Frey, R., \& Embrechts, P. (2015). Quantitative risk management: Concepts, Techniques and Tools. Princeton: Princeton University Press.

[79] Mikes, A. 2009. "Risk Management and Calculative Cultures," Management Accounting Research, 20, no. 1: 18-40.

[80] Moeller, R.R. 2007. COSO Enterprise Risk Management - Understanding the New Integrated ERM, Framework. New Jersey: John Wiley \& Sons.

[81] Moody, M. J. 2013. "Establishing a Safety Culture: Key Success Factor," Rough Notes, Sept. p. 172-173.

[82] Moore, S. H., \& Burgess, A. 2011. "Risk Rituals?” Journal of Risk Research, 14 (1): 111-124.

[83] Morris, M. 2014. "Values as the Essence of Culture," Journal of Cross-Cultural Psychology, 45(1): 14-24.

[84] Morrison, D. 2014. "The Main Ingredient of Change," Harvard Business Review, September: 92 (9): 36.

[85] Mouwad, J. 2011. "Details, Details," New York Times, May 19, p. B1.

[86] Mouton, N., S. N. Just \& J. Gabrielsen. 2012. "Creating Organizational Cultures. Re-Conceptualizing the Relations Between Rhetorical Strategies and Material Practices," Journal of Organizational Change Management, 25(2): 315-331.

[87] Mutzabaugh, B. 2013. "Delta CEO Gives Up Set for Mom Late to Pick Up Daughter," USA Today, June 26,http://www.usatoday.com/story/ todayinthesky/2013/06/25/delta-ceo-gives-up-seat-for-mom-late-to-pickup-daughter/2457095/ 
[88] Naevestad, T. 2009. "Mapping Research on Culture and Safety in HighRisk Organizations: Arguments for a Sociotechnical Understanding of Safety Culture," Journal of Contingencies and Crisis Management, June, 7 (2): 126-136.

[89] Nevis, E. C. 1987. Organizational Consulting: A Gestalt Approach. New York: Gardner Press.

[90] Nisbet, R. A. 1969, The Quest for Community, New York: Oxford University Press

[91] NPR 2013. "Delta Airlines Fined For the Way It Bumps Passengers," June 17, http://www.npr.org/2013/06/27/196133583/the-last-word-inbusiness .

[92] O'Reilly, C. 1989. "Corporations, Culture and Commitment: Motivation and Social Control in Organizations," California Management Review, 31(4): 9-25.

[93] Ott, J. S. 1989. The Organizational Culture Perspective. Pacific Grove: Brooks/Cole Publishing Co.

[94] Pagach, D. \& R. Warr. 2011. "The Characteristics of Firms that Hire Chief Risk Officers," Journal of Risk and Insurance, 7(1): 195-211.

[95] Pidgeon, N., R. E. Kasperson \& P. Slovic. 2003. The Social Amplification of Risk. Cambridge: Cambridge University Press.

[96] Pina e Cunha, M., A Rego, \& A. Vaccaro. 2014. "Organizations as Human Communities and Internal Markets: Searching for Duality," Journal of Business Ethics, (April) 120: 441-455.

[97] Potter, P. \& M. Toburen. 2016. "The 3 Lines of Defense for Good Risk Management," Risk Management, June 1, http://www.rmmagazine.com/ 2016/06/01/the-3-lines-of-defense-for-good-risk-management/.

[98] Reiss, R. 2009. "How Ritz-Carlton Stays at the Top," Forbes Oct. 30, http://www.forbes.com/2009/10/30/simon-cooper-ritz-leadershipceonetwork-hotels.html.

[99] Reissner, S. 2011. "Patterns of Stories of Organisational Change," Journal of Organizational Change Management, vol. 24 (5): 593-609.

[100] Roeschmann, A. 2014. "Risk Culture: What It Is and How It Affects an Insurer's Risk Management," Risk Management and Insurance Review, 17: 277-296.

[101] Røyrvik, E. 2013, "Incarnation Inc. Managing Corporate Values," Journal of Business Anthropology, Spring 2(1): 9-32. 
[102] Schein, E. H. 2004. Organizational Culture and Leadership, 3rd ed. San Francisco: Jossey-Bass.

[103] Schein, E. H. 2010. Organizational Culture and Leadership, 4th. ed. Hoboken: Jossey-Bass.

[104] Scott, W. R. 2004. "Reflections on a Half-Century of Organizational Sociology," Annual Review of Sociology, 30: 1-21.

[105] Segal, S. 2011. Corporate Value of Enterprise Risk Management. Hoboken: John Wiley \& Sons, Inc.

[106] Singer, N. 2014. "Intel's Sharp-Eyed Social Scientist," New York Times, February 15, p. BU1.

[17] Solomon, R. C. 1992. Ethics and Excellence: Cooperation And Integrity In Business. New York: Oxford University Press.

[108] Sørensen, J. B. 2002. "The Strength of Corporate Culture and the Reliability of Firm Performance," Administrative Science Quarterly, February, 47(1): 70-91.

[109] Stahel, W. R. 2002. The Geneva Papers on Risk and Insurance, February, 27(2): 268-274.

[110] Swedbank 2010. Annual Report 2010.http://www.swedbank.com/ investor-relations/financial-information-and-publications/annualreport-2010/risk-management/swedbanks-three-lines-of-defence/ index.htm

[111] Tharaldsen, J., \& Haukelid, K. 2009. "Culture and Behavioural Perspectives On Safety - Towards A Balanced Approach," Journal of Risk Research, 12(3/4): 375-388.

[112] Tian, R. G. 2010. "The Unique Contributions and the Unique Methodologies: A Concise Overview of the Applications of Business Anthropology," International Journal of Business Anthropology, 1(2): 70-88.

[113] Tian, R. \& A. Walle. 2009. "Anthropology and Business Education: Practitioner Applications For A Qualitative Method." International Journal of Management Education, 7(2): 59-67.

[114] Tobin, R. 2010. "Ego is Not in Blake's Toolbox: Home Depot CEO Tries to Rebuild Company's Early Foundation." Atlanta Journal-Constitution, August 29: D1.

[115] Trice, H. M. \& J.M. Beyer 1984. "Organizational Cultures Through Rites and Ceremonials," Academy of Management Review, 94(4): 653-669. 
[116] Trice, Harrison M. \& Beyer, Janice M. 1993. The Cultures of Work Organization. Englewood Cliffs: Prentice Hall.

[117] Van de Ven, A.H., \& M.S. Poole. 1995. "Explaining Development and Change in Organizations," Academy of Management Review, 20(3): 510-540.

[118] Vlasic, B. 2014. "G.M. Inquiry Cites Years of Neglect Over Fatal Defect," New York Times, June 6: A1.

[119] Visschers, V. M., Wiedemann, P. M., Gutscher, H. H., Kurzenhäuser, S. S., Seidl, R. R., Jardine, C. G., \& Timmermans, D. M. 2012. "Affect-inducing Risk Communication: Current Knowledge and Future Directions," Journal of Risk Research, 15(3): 257-271.

[120] Watkins, M. D. 2007. "Help Newly Hired Executives Adapt Quickly." Harvard Business Review, 85(6), 26-30.

[121] Weick, K.E. \& K. M. Sutcliff. 2001. Managing the Unexpected. San Francisco: Jossey-Bass.

[122] Weick, K. E \& R. E. Quinn. 1999. "Organizational Change and Development," Annual Review of Psychology, 50: 361-386.

[123] Weick, K. E. 1987. "Organizational Culture as a Source Of High Reliability," California Management Review: CMR 29(2): 112-127.

[124] Wendling, C. 2012. "What Role for Social Scientists In Risk Expertise?" Journal of Risk Research, May, 15(5): 477-493.

[125] Whyte, W. H. 1956. The Organization Man. New York: Simon \& Schuster.

[126] Wiessner, P. 2014. "Embers of Society: Firelight Talk Among the $\mathrm{Ju} /$ 'hoansi Bushmen," Proceedings of the National Academy of Sciences, 111(39), 14027-14035.

[127] Wood, G. 2013. "Anthropology, Inc.," The Atlantic, 311(2), March, p. $48-56$. 


\section{NOTES}

1. Harold Weston, Clinical Associate Professor, Department of Risk Management and Insurance, Robinson College of Business, Georgia State University, Atlanta, GA, hweston@gsu.edu.

2. Thomas A. Conklin, Clinical Associate Professor, Department of Managerial Sciences, Robinson College of Business, Georgia State University, Atlanta, GA, tconklin@gsu.edu.

3. Kristen Drobnis, Adjunct Professor, Project Management, College of Professional Studies, Northeastern University, Boston, MA, k.drobnis@neu.edu.

4. Contingency, transaction, resource dependence, network, organizational ecology, and institutional (Scott 2004, 5-7). Life cycle, teleological, dialectical and evolutionary (Van de Ven \& Poole 1995, cited in Weick 1999, 364.) Bolman and Deal offer "frames" of function, human resource, and symbolic (culture), (Bolman and Deal 2008, 15-16).

5. The use of stories is expanded in an excellent discussion of rhetoric to affect culture, in Mouton, et al. (2012). For a constrained use of the idea of risk rhetoric, being about political sensitivity in the organization for bad news, see Harwood (2009). 


\section{APPENDIX - SURVEY QUESTIONS}

A few preliminary questions about you and your organization.

Is your firm:

$\square$ Public $\square$ Private

$\square$ Domestic $\square$ International

$\square$ Less than $\$ 100$ million

$\square$ 100m-1 billion

$\square$ greater than 1 billion

Salary budget for risk department?

$\$$

Program or initiative budget?

$\$$

Risk insurance premiums paid per year?

$\$$

Number of employees with direct risk

management responsibility including you? 


\section{APPENDIX A}

1. To what extent are you familiar with the idea of a "risk aware" culture for enterprise risk management?

Not at all

Thoroughly familiar
1
2
3
4
5
6
7

2. Does your firm have what you would describe as a risk aware culture?

Not at all

Fully embedded

$\begin{array}{lllllll}1 & 2 & 3 & 4 & 5 & 6 & 7\end{array}$

3. Prior to beginning your survey of firm culture, please rate the level of the current risk aware culture at your firm?

Fully embedded

Not at all in our culture
1
2
3
4
5
6
7

4. Has your firm hired (or have on staff) someone knowledgeable about organizational culture?

$\square$ Yes $\square$ No

5. Are you aware of the work and techniques of Edgar Schein, John Kotter, or anyone else who studies, writes, and consults about firm culture?

$\square$ Yes $\square$ No

6. Please describe briefly what you understand to be a risk aware culture? 
7. What techniques, frameworks, tools or methods do you or your firm use to understand the culture of your firm?

8. What techniques, frameworks, tools or methods have you or your organization used to shape or change your firm's culture to a risk aware culture?

9. To what extent have these processes achieved their intended result?

$\begin{array}{llllllll}\text { Not at all } & & & & & & & \begin{array}{r}\text { illy embed } \\ \text { in our culture }\end{array} \\ 1 & 2 & 3 & 4 & 5 & 6 & 7 & \text { N/A }\end{array}$

10. How would you describe your firm's culture? 


\section{TABLE 1 RESPONSES FROM ALL RESPONDENTS TO QUALITATIVE SURVEY QUESTIONS}

\section{Q6 - Please describe briefly what you understand to be a risk aware culture.}

- Risk assessments are considered prior to taking on new activities.

- A philosophy that is thoroughly understood and agreed by all levels of an organization (CEO to new hourly to contractor) that risks must be evaluated before beginning any task, no matter how routine.

- a set of values, beliefs, knowledge and understanding surrounding risks that are shared by a group of corporate citizens with a common objective of furthering a corporate mission.

- One that is careful in which clients/subs it works with and mitigates risk through contractual or other vehicles, and brings in the right people early on when issues come up to mitigate the risk of claims.

- People strive to intimately understand the risks inherent in their own areas of responsibility; and their impact on risks in other areas of the enterprise.

- Risk is embedded in all decisions.

- Considering risk vs. rewards in decision making

- Company-wide culture that is aware of the different types of risks, knows how to identify them, and who and how to escalate them.

- Aware that each team member owns risk within the processes for which they are responsible. Decisions should be measured against the Board approved risk appetite.

- Employees are aware of risk and not afraid to raise concerns

- Having values and beliefs that are inculcated into the corporate culture and allowing each staff member the ability to stop a project if the risk is to great at the moment.

- Creating an environment in which identification and reduction of hazards are addressed prior to a claim. This behavior also should be encouraged or celebrated.

- An environment where individuals understand the company's business values, goals (and services/products) and, in turn, recognize, address and take responsibility for risk management

- The way employees in an organization think about and implement risk taking. Risk taking attitudes are driven by organizational norms, expectations and incentives.

- Understanding of risk both vertically and horizontally. Embedded in daily tasks, measured in outcomes, considered in evaluations and incentives.

- It is all about core values of an organization. It starts with tone at the top but also through shared values is driven through the organization to each employee to where "doing the right thing" simply becomes the way of doing business. Companies with strong risk cultures have employees that embrace this as personal value. Everyone is responsible for managing risk whether it is safety, security, compliance etc.

- It is an organization-wide mindset when all associates fully recognize, embrace, and proactively manage risks and opportunities

- Our Risk Management organization is a strategic business unit that supports Company objectives by addressing the full spectrum of its risks and managing the combined impact of those risks as an interrelated risk portfolio.

- Decisions are based with understanding of the risk associated with business opportunities. Risk is measures across the enterprise and risk mitigating steps are taken.

- A culture where it becomes second-nature to proactively recognize and mitigate or transfer risks before hey threaten.

- We have implemented a Behavior based safety awareness program and have extended that to all things related to risk across the enterprise 


\section{Q7 - What techniques, frameworks, tools or methods do you or your firm use to understand the culture of your firm?}

- Not sure

- Safety shares at the beginning of every meeting. Evaluating every task before beginning. Training, discussions, management, leadership, all make safety and risk awareness THE priority. If we can't do something safely, we WON'T do it.

- Academy, M\&A Due Diligence, claims reviews, predictive models, incident reviews

- Risk Management department; contract worksheets for project managers, risk and approval matrix, training

- "Leaders as Teachers" forums where execs educate employees of how each department fits in the organizational puzzle, and various ways of showing that the value of the enterprise is greater than the sum of the values of its parts. than the

- interviews and awareness

- benchmarking survey, internal review of issues and gaps, and surveys.

- We require training on the enterprise risk framework annually. The training covers roles and responsibilities for the three lines of defense: Audit, Risk Functions and the Lines of Business. We had risk liaisons embedded in all lines of business that are high level managers responsible for integrating risk within the LOB, and serving in communication and coordination roles. The lines of business conduct risk self-assessments. New product risk assessment ensures that we do not go to market with any product without a thorough understanding of the risks, and having the risks mitigated to an acceptable level.

- Lean Residual risk reduction (R3 - gets at root of risk to make corrections)

- Three lines of defense

- Of the four major corporate cultures, Clan, Adhocracy, Market and Hierarchy. We are a tall hierarchy.

- Dupont Consulting survey, and interviews.

- Company and locate engagement surveys; Insurance company and internal audits; New hire and continuing education/training

- Surveys of leaders and employees. A leadership model framework that includes management of risk and opportunity.

- surveys, claims, trends, asking the question, observation

- ERM Process modeled after COSO framework. Culture is reviewed/discussed with regards to its impact on managing risk. Other tools used by HR.

- risk management capability assessments, audits, employee engagement surveys

- Follow industry best practices and we have developed and adopted the following framework to manage our corporate policies: Development Approval Delivery Dissemination Affirmation Training

- Frameworks are driven by Internal Audit

- No formal techniques, frameworks, tools or methods that I am currently aware of.

- ERM Framework model 
Q8 - What techniques, frameworks, tools or methods have you or your organization used to shape or change your firm's culture to a risk aware culture?

- Top down approach to supporting risk awareness. Designated a single point of contact to manage the risk mgt program.

- Safety shares at the beginning of every meeting. Evaluating every task before beginning. Training, discussions, management, leadership, all make safety and risk awareness THE priority. If we can't do something safely, we WON'T do it.

- Matter Mgmt. thorough claims reviews and incident reviews

- Risk Management department; contract worksheets for project managers, risk and approval matrix, training

- Interdepartmental risk assessments and cross-training.

- Transparency and open communication

- Leadership messaging and business processes

- We use education and training, Tone at the Top is focused on Risk mitigation. Policies and Procedures, oversight groups, 1 GRC system used to track issues.

- To supplement risk self-assessments, a business process owner survey is conducted at least twice each year to determine if there have been changes in the risk environment - staffing changes, significant loss events, control changes, breaches of KRI's, etc. Risk liaisons within the lines of business have helped to integrate risk awareness into the culture. All job descriptions and performance reviews include some form of risk responsibility.

- Loss control

- adding an item to every employees performance objective on Risk Management.

- Kurt Lewin's force field model has been used in a couple of departments. People are very resistant to disruptive change. Difficult, but not impossible to achieve.

- Dupont management training, email awareness of common hazards, audit of locations.

- Local, regional and specialty Safety Advocates; Functional and location audits; distribution of internal and industry trade information; Exposure-based allocations of premiums

- Created a leadership model. Have undertaken culture change initiatives that address accountability. CEO communications.

- trainings, forums, incentives

- Core Values, Policy Book, Business Conduct \& Compliance, etc. etc. etc.

- Elearning modules, risk workshops, executive messaging, policies

- By taking a holistic approach to managing our policies and procedures, the EPMO provides value through managing and disseminating policy content, standardizing practices and delivering a consistent employee experience.

- Risk maps, top-down approach to prioritization

- We are at the onset of shifting our culture to a "risk aware" culture. The first step we've taken is to impact our stores financially at the time of a loss by raising their deductibles. Corporately, we have a high deductible program but we have never passed that cost down to the store level. As such, they were not aware of the financial impact their losses have on our company. Now they have more "skin in the game" so to speak. To go along with the higher deductibles, the Risk Management department issued guidelines to assist the stores in enhancing their individual safety cultures and try to prevent losses (and avoid the higher financial impact). It's a baby step, but it's a step in the right direction.

- Behavior based awareness training model 